\title{
Individual Intelligence as One of Competency Assessments and Performance of Employees in State-Owned Cement Enterprises
}

\author{
Andi Ririn Oktaviani' ${ }^{1}$, Siti Haerani ${ }^{2}$, Muh. Asdar ${ }^{3}$ and Muh. Ismail ${ }^{4}$ \\ ${ }^{1}$ Hasanuddin University, e-mail: rhien_octaviany@yahoo.co.id \\ ${ }^{2}$ Hasanuddin University, e-mail: haeranisiti68@yahoo.co.id \\ ${ }^{3}$ Hasanuddin University \\ ${ }^{4}$ Hasanuddin University
}

\begin{abstract}
Individual intelligence of employees has an important role as a stimulus to achieving competency standards based on competency dictionaries in state-owned cement companies in Indonesia. Employee competency assessment is an indicator established by a company that reflects the behavior that must be carried out by each employee in carrying out their duties and responsibilities and is closely related to the level of employee performance achievement. Data analysis used by SEM and consisted of 399 samples of BUMN cement employees. The results of this study indicate that the intellectual, emotional, spiritual, and physical intelligence of employees in state-owned cement companies on average are quite high and fulfill competency and performance standards in the categories of satisfactory and very good.
\end{abstract}

Keywords: Individual intelligence, competency standard

\section{Introduction}

Today the company is increasingly selective in choosing potential employees who have capable abilities and one of the determining factors is intelligence that not only consists of one common factor, but also consists of more specific factors such as intellectual intelligence, emotional intelligence, spiritual intelligence and physical intelligence. The existence of a large organizational structure with many and varied work units, as well as differences in the intelligence characteristics of each individual employee, causes the attributes in the form of assessment criteria to achieve competency and performance needs to be clearly formulated by the management of state-owned cement companies. There are several theoretical differences regarding intelligence factors that predominantly produce competencies and work performance of each individual, including (Goleman, 1996) view that emotional intelligence (EQ) is more important than intellectual intelligence (IQ) measured by standard tests on cognitive, verbal and nonverbal intelligence which was denied by (McCrae and Costa, 1987), (Mayer et al., 2001), (Crawford, Howell and Garthwaite, 1998), and (Chan, Peelen and Downing, 2004), who stated that Goleman's views were inappropriate because they did not place serious attention to individual emotional values and in-depth academic studies. Spiritual intelligence factors also arise because many researchers argue about intellectual intelligence and emotional intelligence which are seen as contributing only part of the determinants of individual success so that other factors that also play a role are spiritual intelligence that emphasizes the meaning of life and not only limited to religious emphasis (Haxby, Hoffman and Gobbini, 2002). Physical intelligence is also considered to be considered to complement the other three intelligences. A person with high IQ, EQ, and SQ will not be able to work well in a condition of fatigue, illness or physical condition (Joh et al., 2002).

Intelligence is closely related to the cognitive abilities possessed by each individual employee in the form of the ability to reason, plan, solve problems, think abstractly, understand ideas, use language and learn (Weschler, 1958), (Kolb, 1984), (Sternberg, 1999). In line with this, several previous studies also found that there needs to be a special approach to managing the intelligence that employees have to produce competent employees and will have a positive impact on individual employee performance 
and company performance (Dessler, 2011), (Beardwell, Holden and Claydon, 2004), (Snape, Redman and Wilkinson, 1993); (Torrington, Hall and Taylor, 2009).

Employee performance is one of the most frequently studied concepts in the fields of management science and organizational psychology, but many psychological contents from this topic is not yet explained. Employee feel valued if his intelligence is used to carry out work and receives better rewards and career opportunities based on the competencies and performance they show. Employee performance appraisal is the answer to the success or failure of the stated company goals. Company management needs to pay attention to the performance of its employees so that they do not face a potential human resource crisis.

Intellectual Intelligence Concept. Intellectual intelligence is the intelligence of thinking and brilliant reason that manages the right brain and the left brain in a balanced manner. Global cognitive abilities possessed by individuals so that they can act in a direction and think meaningfully to solve problems (Trihandini, 2013), and (Deary, 2012).

Spearman groups intelligence into two categories. The first category is g factor or commonly referred to as cognitive abilities possessed by individuals in general, such as the ability to remember and think. The second category is called the $\mathrm{s}$ factor which is a special ability that is owned by an individual, Eysenck (1981) states that more factors are the basic potential of everyone to learn and adapt. This intelligence is influenced by innate factors (s factors). S factor is intelligence that is influenced by the environment so that the factors that are owned by one person will be different from the others. Each factor must contain $g$ factors.

Emotional Intelligence Concept. (Salovey and Mayer, 1990), (Lenaghan and Sengupta, 2007), (Cherniss, 1998), and (Petrides, 2011) state that emotional intelligence is a person's ability to monitor Her feelings and emotions both for herself and for others, are able to distinguish the two things and then use that information to guide her thoughts and actions so as to achieve the goal of building productive relationships and achieving work success.

Emotional intelligence expert, presented five skills in emotional intelligence, which are divided into personal skills and social skills, namely self-awareness, self-management, motivation, empathy, and social skills (Goleman, Boyatzis and McKee, 2013).

Several studies have shown that brain intelligence only accounts for about 20 percent of the factors that determine success in life, and the other 80 percent is filled by other forces including emotional intelligence which includes the ability to motivate yourself and endure frustration, control impulses heart and not exaggerate pleasure, regulate mood and maintain the burden of stress so as not to paralyze the ability to think, empathize and pray (Thoits, 2013).

(Goleman, 1998) and (Brown, Bryant and Reilly, 2006), revealed that brain intelligence is not a dominant predictor in one's career development, but emotional intelligence. The higher the position of a person in a company, the more crucial the role of emotional intelligence. Corporate leaders need high emotional intelligence because they represent the organization and interact with many people both inside and outside the organization and play an important role in shaping the morale and discipline of its employees. Leaders who have high empathy will be able to understand the needs of their employees and can provide constructive feedback. The fundamental value developed by displaying emotional intelligence in the world of work is the implication of the implementation of training, by noting that emotional intelligence plays an active role in one's success at work.

Spiritual Intelligence Concept. Currently the world of work brings more concentration on spiritual problems. Employees get life values not only at home, but they also look for every meaning of life that comes from their work environment. Those who can give meaning to their lives and bring spirituality into the work environment will make them better people so that the resulting performance is better than those who work without having spiritual intelligence (Russell, 1997).

The term spiritual intelligence began to emerge because many people were arguing about intellectual intelligence and emotional intelligence that were seen as only contributing part of the determinant of one's success in life. Another factor that also plays a role is spiritual intelligence which emphasizes 
more on the meaning of life and is not limited to the emphasis of religion alone (Rouach and Santi, 2001).

Spiritual intelligence allows one to unite intrapersonal and interpersonal things, and bridge the gap between self and others (Malone, Laubacher and Dellarocas, 2010).

Likewise, the al-Qur'an verse that teaches thinking and learning. Curiosity becomes very important in life and this can only be realized if we are always able to think (Crowne, 2009).

Physical Intelligence Concept. Physical intelligence is a person's ability to maintain their own fitness or health. All people who study, work or seek success in life because they have to work hard to get what they want. Therefore, maintaining health is an important matter (Gilad, 2011) and (Hulnick, 2006). Physical intelligence complements the three intelligences that a person has, namely intellectual intelligence, emotional intelligence, and spiritual intelligence. A person with high IQ, EQ, and SQ will not be able to work well in conditions of fatigue, illness or physical condition.

Roman quote "Mens there in corpore sano" which means in a strong body there is a healthy soul. With a healthy body, the body, brain, and mind will be healthy. Physically the most decisive or most influential part of a person's emotional intelligence is his emotional nerve anatomy. The part of the brain used to think is context (sometimes also called neo context). As part of the part of the brain that deals with emotions the limbic system, but actually between these two parts determines a person's emotional intelligence.

The Concept of Employee Competency. (Mathis and Jackson, 2002) argues that competence shows the characteristics that underlie behavior that describes motives, personal characteristics, selfconcept, values, knowledge or expertise brought by someone who is superior performer in the workplace.

Competence is said to be an underlying characteristic because individual characteristics are a deep and inherent part of a person's personality that can be used to predict certain job situations. Then it is said to be related to behavior and performance because competence causes or can predict behavior and performance.

It is this discrepancy in competencies that distinguishes a superior actor from a limited achiever. Limited competence and special competencies for a particular job are patterns or guidelines in employee selection, task shifting planning, work assessment and development (Ulrich, 1997), (Henderson, 1993), (Haydock, Connor and Dawes, 1995), (Boyatzis and Boyatzis, 2008), (Boyatzis, 2009), (Callen, 2002), (Fardmanesh, Ebrahimi and Taheri, 2012), (Gribble, 1991), (Boyatzis, 2005), (McClelland et al., 1998), (Getha-Taylor et al., 2010), (Vathanophas, Vichita; Thai-ngam, 2007), (Boyatzis, Goleman and Rhee, 2000) and (Hagan, 1996).

Boyatzis emphasized that competence is a real aspect of humans. Boyatzis's superiority from previous researchers is his great desire to build this concept to be richer and more detailed. Regarding the understanding of competence as an underlying characteristic, Spencer and Spencer said there are five types of competency characteristics namely motives, traits, self-concept, knowledge, and skills.

Competency Analysis Methodology. According to (Mathis and Jackson, 2002), flexibility is very varied and some can be seen clearly and hidden. The visible competencies explain the example of employees in positions that are in accordance with knowledge that uses the ability to make financial statements, while the abilities used to solve problems and the ability to collaborate with company relationships or create strategic concepts that have implications for performance improvement.

Competencies established in the organization are the basis of various aspects of resource development that are conditioned as supporters in the organization. Performance is an important capital to get the organization to achieve an optimal and efficient level of excellence.

Competency Based on HR Functions. The thoughts of other experts can be identified several main points about the qualities that individuals need to have as executives, managers, and employees. Employee competence is needed to identify jobs that are in line with the expected achievements. Employee level competencies include flexibility, information seeking, motivation, and ability to 
learn, achievement motivation, work motivation under time pressure, collaboratives, customer service orientation.

The competency processing process has also been developed in such a way as to keep up with the times. One of them is through assessment. Assessment of the competency processing process is more likely to provide feedback on the competencies possessed by employees in general. This method uses motivation to encourage employees to understand correctly the competencies they have and the work that has been done.

Employee Performance Concept. Employee performance in the company is the answer to the success or failure of the stated organizational goals. Some company management often does not pay attention to the performance of subordinates so that companies sometimes face serious crises. Work performance directly affects individual employee satisfaction through the suitability of intelligence and competencies used in the execution of work. While the achievement of high levels of employee performance is one of the functions of the absence of obstacles that become obstacles to employees at work (Robbins, 1996).

Individuals who have high performance have several characteristics such as achievement-oriented, self-confidence, self-control, and competence (Mink, 1993).

The factors that influence individual employee performance are their abilities, motivation, support received, the existence of the work they do, and their relationship with the organization (Mathis and Jackson, 2002).

Good performance is a step towards achieving organizational goals, therefore performance is also a decisive means in achieving organizational goals so that it needs to be strived to improve employee performance. Performance assessment is used to measure individual employee contributions to the company where they work as a systematic description or description of the strengths and weaknesses associated with a person or group. Periodic and systematic evaluation of work performance based on the authority and position of an employee, including the potential for development.

\section{Research Methodology}

The method used to collect data in this study uses questionnaires and interviews.

This study uses an explanatory pattern that intends to explain the position of the variables studied and the relationship between one variable and another. In explanatory, it is carried out in two phases, in the first stage emphasizes quantitative data collection and analysis then continues with a qualitative approach to describe or further explain quantitative findings.

The population in this study were all organic or permanent employees of PT Semen Indonesia, PT Semen Padang, PT Semen Tonasa, and PT Semen Gresik totaling 5,122 employees.

The sampling technique used in this study uses a quota sampling technique that can ensure that certain groups are adequately represented in the research through the use of a quota of 399 employees.

This type of research for this dissertation can be classified as basic research.

The analysis technique used to analyze the data is the analysis of structural equation models (SEM). Conceptual Model. In this research, the author wants to analyze the intelligence of individual employees as one of the prerequisites for achieving employee competencies and performance as shown in Figure 1 below; 


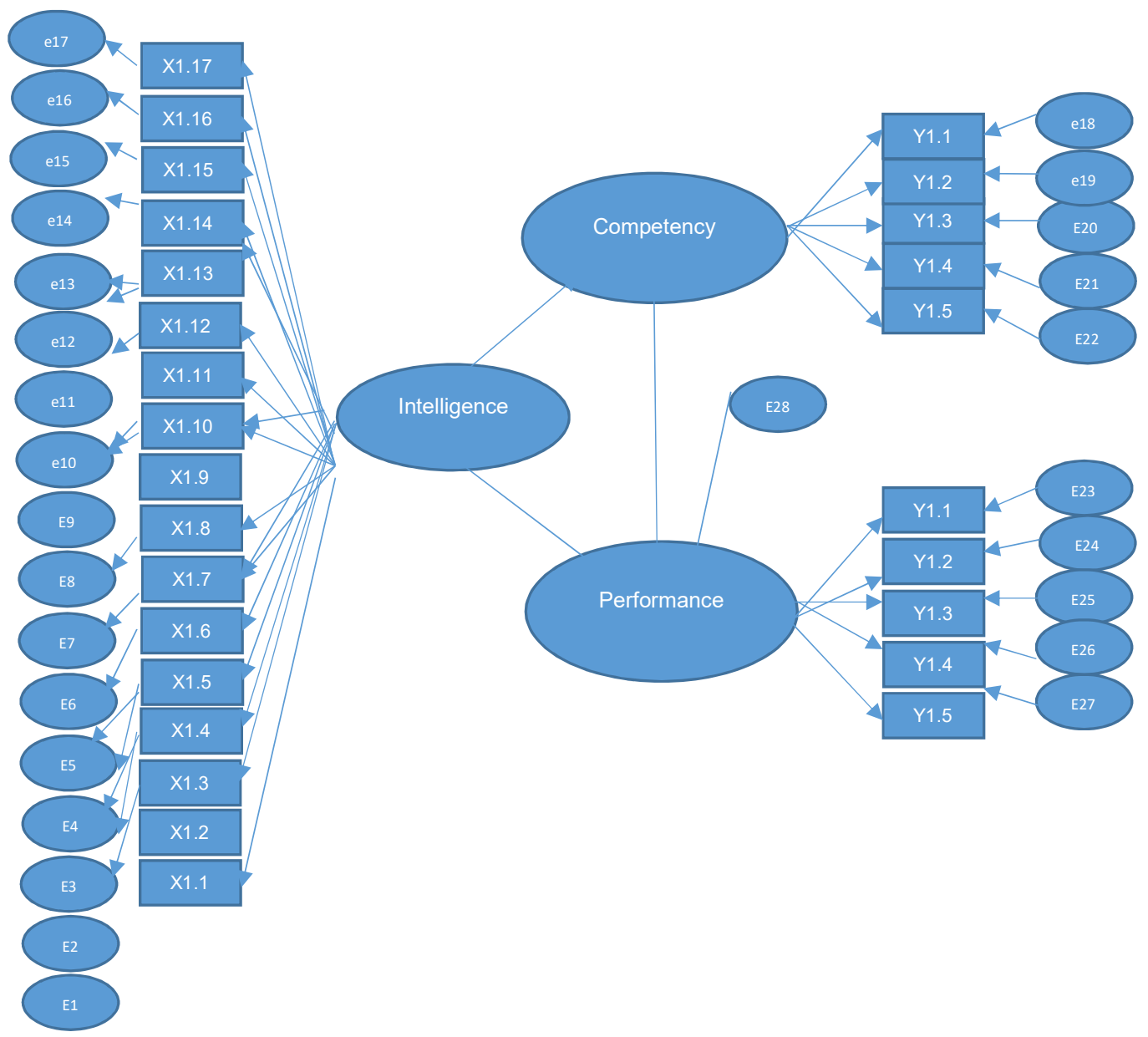

Figure 1. Structural relationship among variables

\section{Result and Discussion}

Intelligence variables can predict competency variables. The positive role of intelligence variables in relation to human resource strategies and the performance of knowledge-based innovation can be a sustainable source of profit because of the knowledge and social complexity of human assets that are difficult to imitate. All SOE cement company employees are required to have high competence as a benchmark for the realization of behavior that must be carried out by each employee in carrying out their duties and responsibilities. Specifically, the intended competencies are core competencies, leadership competencies, and technical competencies in accordance with the placement of employees by considering individual abilities (individual profile), job characteristics (job profile) and employee work experience (history requirements). These three characteristics based on the characteristics of respondents (age, gender, education, years of service and echelon level) described in chapter 5 are prerequisites for the management of cement companies to determine the placement or grouping of employees into certain work units.

The framework based on employee competency is the mixing of behavior, values, tasks and personal characteristics which are a combination or synergy of intellectual intelligence, emotional intelligence, spiritual intelligence, and physical intelligence. 
Table 1. Confirmatory Evaluation of Variable Intelligence Factors

\begin{tabular}{|c|c|c|c|c|c|c|}
\hline Indicator & $\begin{array}{l}\text { Standard } \\
\text { Loading }\end{array}$ & $\begin{array}{l}\text { Standard } \\
\text { Loading }^{2}\end{array}$ & $\begin{array}{l}\text { Construct } \\
\text { Reliability }\end{array}$ & $\begin{array}{l}\text { Average Variance } \\
\text { Extracted (AVE) }\end{array}$ & $\begin{array}{c}\text { Interprets } \\
\text { Validity Check }\end{array}$ & $\begin{array}{c}\text { Interprets } \\
\text { Reliability } \\
\text { Check }\end{array}$ \\
\hline 1 & 0,675 & 0,456 & \multirow{18}{*}{0,926} & \multirow{18}{*}{0,846} & \multirow{18}{*}{ Valid } & \multirow{18}{*}{ Reliable } \\
\hline 2 & 0,710 & 0,504 & & & & \\
\hline 3 & 0,733 & 0,537 & & & & \\
\hline 4 & 0,720 & 0,518 & & & & \\
\hline 5 & 0,726 & 0,527 & & & & \\
\hline 6 & 0,794 & 0,630 & & & & \\
\hline 7 & 0,705 & 0,497 & & & & \\
\hline 8 & 0,754 & 0,569 & & & & \\
\hline 9 & 0,731 & 0,534 & & & & \\
\hline 10 & 0,646 & 0,417 & & & & \\
\hline 11 & 0,565 & 0,319 & & & & \\
\hline 12 & 0,626 & 0,392 & & & & \\
\hline 13 & 0,622 & 0,387 & & & & \\
\hline 14 & 0,478 & 0,228 & & & & \\
\hline 15 & 0,456 & 0,208 & & & & \\
\hline 16 & 0,571 & 0,326 & & & & \\
\hline 17 & 0,490 & 0,240 & & & & \\
\hline TOTAL & 11,002 & 7,291 & & & & \\
\hline
\end{tabular}

Source: Data 2018

Based on Table 1. above there are 3 indicators with a standard loading value $<0.5$ which is indicator 14 with a loading standard of 0.478 , indicator 15 with a loading standard of 0.456 and indicator 17 with a loading standard of 0.490 so that the indicator is removed from the model. And then retesting. Test results can be seen in table 5.2. next;

Table 2. Confirmatory Evaluation of Elimination Result Intelligence Variable Factors

\begin{tabular}{|c|c|c|c|c|c|c|}
\hline Indicator & $\begin{array}{l}\text { Standard } \\
\text { Loading }\end{array}$ & $\begin{array}{l}\text { Standard } \\
\text { Loading }\end{array}$ & $\begin{array}{l}\text { Construct } \\
\text { Reliability }\end{array}$ & $\begin{array}{l}\text { Average Variance } \\
\text { Extracted (AVE) }\end{array}$ & $\begin{array}{c}\text { Interprets } \\
\text { Validity } \\
\text { Check }\end{array}$ & $\begin{array}{c}\text { Interprets } \\
\text { Reliability Check }\end{array}$ \\
\hline 1 & 0,675 & 0,456 & \multirow{15}{*}{0,925} & \multirow{15}{*}{0,856} & \multirow{15}{*}{ Valid } & \multirow{15}{*}{ Reliable } \\
\hline 2 & 0,710 & 0,504 & & & & \\
\hline 3 & 0,733 & 0,537 & & & & \\
\hline 4 & 0,720 & 0,518 & & & & \\
\hline 5 & 0,726 & 0,527 & & & & \\
\hline 6 & 0,794 & 0,630 & & & & \\
\hline 7 & 0,705 & 0,497 & & & & \\
\hline 8 & 0,754 & 0,569 & & & & \\
\hline 9 & 0,731 & 0,534 & & & & \\
\hline 10 & 0,646 & 0,417 & & & & \\
\hline 11 & 0,565 & 0,319 & & & & \\
\hline 12 & 0,626 & 0,392 & & & & \\
\hline 13 & 0,622 & 0,387 & & & & \\
\hline 14 & 0,571 & 0,326 & & & & \\
\hline TOTAL & 9,578 & 6,614 & & & & \\
\hline
\end{tabular}

Source: Data 2018

Based on table 2, the standard value loading indicator $>0.5$ so that all indicators are considered feasible to explain the latent variables developed. The AVE value of the intelligence variable is 0.856 greater than 0.5 . Likewise construct reliability with an acceptable value is a minimum of 0.7 while 
the CR value of the intelligence variable is 0.925 . Thus, the indicators are categorized as valid because average variance extract (AVE) and construct reliability (CR) show the amount of variance of the indicators extracted by the latent variables developed.

Table 3. Direct Influence Testing Results

\begin{tabular}{|l|c|c|c|c|c|c|c|c|}
\hline \multicolumn{2}{|l|}{ Relation type } & Estimate & S.E. & C.R. & P & \multicolumn{2}{|c|}{ Noted } \\
\hline Competence & $<---$ & Intellectual & 0,884 & 0,181 & 4,884 & 0,000 & Significant & Accepted \\
\hline Performance & $<---$ & Intellectual & 0,434 & 0,185 & 2,351 & 0,019 & Significant & Accepted \\
\hline Performance & $<---$ & Competence & 0,304 & 0,093 & 3,269 & 0,001 & Significant & Accepted \\
\hline
\end{tabular}

Source: Data 2018

Table 4. Test Results of Indirect Influence and Total Influence

\begin{tabular}{|l|c|c|c|c|c|c|}
\hline $\begin{array}{c}\text { Var } \\
\text { Independent }\end{array}$ & $\begin{array}{c}\text { Var } \\
\text { Intervening }\end{array}$ & $\begin{array}{c}\text { Var } \\
\text { Dependent }\end{array}$ & C.R & P-Value & \multicolumn{2}{|c|}{ Noted } \\
\hline Intellectual & Competence & Performance & 0,093 & 2,717 & 0,006 & Significant \\
\hline
\end{tabular}

Source: Data 2018

Based on table 3. and table 4. The direct and indirect contribution of intelligence variables to the competence and performance cement employees of state-owned enterprises in Indonesia has a positive and significant influence.

\section{Conclusion}

Intelligence has a positive and significant effect both directly and indirectly on employee performance through competence. Intelligence has a positive and significant effect directly on competence.

\section{References}

Beardwell, I., Holden, L. and Claydon, T. (2004) HUMAN RESOURCE MANAGEMENT: A CONTEMPORARY APPROACH, Endoscopy. doi: 10.1055/s-0031-1291491.

Boyatzis, R. and Boyatzis, R. E. (2008) "Competencies in the 21st century," Journal of Management Development. doi: 10.1108/02621710810840730.

Boyatzis, R. E. (2005) “Competency,” Blackwell Encyclopedic Dictionary of Organizational Behavior.

Boyatzis, R. E. (2009) "Competencies as a behavioral approach to emotional intelligence," Journal of Management Development. doi: 10.1108/02621710910987647.

Boyatzis, R., Goleman, D. and Rhee, K. (2000) "Clustering competence in emotional intelligence: Insights from the Emotional Competence Inventory (ECI)," Handbook of Emotional Intelligence.

Brown, F. W., Bryant, S. E. and Reilly, M. D. (2006) "Does emotional intelligence - as measured by the EQI - influence transformational leadership and/or desirable outcomes?," Leadership \& Organization Development Journal, 27(5), pp. 330-351. doi: 10.1108/01437730610677954.

Callen, J. (2002) "Which competencies do health information managers working in public hospitals perceive to be important for effective performance?," The HIM journal.

Chan, A. W. Y., Peelen, M. V. and Downing, P. E. (2004) "The effect of viewpoint on body representation in the extrastriate body area," NeuroReport. doi: 10.1097/00001756-20041025000021.

Cherniss, C. (1998) "Bringing emotional intelligence to the workplace," ... Intelligence in ..., pp. 134. doi: http://www.eiconsortium.org/reports/technical_report.html. 
Crawford, J. R., Howell, D. C. and Garthwaite, P. H. (1998) "Payne and Jones Revisited: Estimating the Abnormality of Test Score Differences Using a Modified Paired Samples t Test," Journal of Clinical and Experimental Neuropsychology. doi: 10.1076/jcen.20.6.898.1112.

Crowne, K. a (2009) "The relationships among social intelligence, emotional intelligence and cultural intelligence," Organization Management Journal, 6(3), pp. 148-163. doi: 10.1057/omj.2009.20.

Deary, I. J. (2012) “Intelligence," Annual Review of Psychology, 63, pp. 453-482. doi: 10.1146/annurev-psych-120710-100353.

Dessler (2011) "Manajemen SDM," Manajemen SDM.

Fardmanesh, H., Ebrahimi, M. and Taheri, A. (2012) "Presentation model of managerial competency approach in management development," Advances in Environmental Biology.

Getha-Taylor, H. et al. (2010) "Competency Model Design and Assessment: Findings and Future Directions," Journal of Public Affairs Education.

Gilad, B. (2011) "Strategy without intelligence, intelligence without strategy," Business and Economics Managemnt, 12(1), pp. 4-11. doi: 10.1108/17515631111106821.

Goleman, D. (1996) "Emotional intelligence: Why it can matter more than IQ," Nature. doi: 10.1016/j.paid.2003.12.003.

Goleman, D. (1998) Working with Emotional Intelligence, Futurist. doi: 98-18706 Library of Congress.

Goleman, D., Boyatzis, R. and McKee, A. (2013) "Primal Leadership: Unleashing the Power of Emotional Intelligence," Harvard Bus Review Press. doi: 10.1109/EMR.2009.5235507.

Gribble, K. (1991) “Competence at work," Library Management. doi: 10.1108/EUM0000000000837. Hagan, C. M. (1996) "The core competence organization: Implications for human resource practices," Human Resource Management Review. doi: 10.1016/S1053-4822(96)90017-0.

Haxby, J. V., Hoffman, E. A. and Gobbini, M. I. (2002) "Human neural systems for face recognition and social communication," Biological Psychiatry. doi: 10.1016/S0006-3223(01)01330-0.

Haydock, W., Connor, J. and Dawes, F. (1995) "Management development: A personal competency approach," Training \& Management Development Methods.

Henderson, I. (1993) “Action Learning: A Missing Link in Management Development?," Personnel Review. doi: 10.1108/EUM0000000000813.

Hulnick, A. S. (2006) "What's wrong with the Intelligence Cycle," Intelligence and National Security, 21(6), pp. 959-979. doi: 10.1080/02684520601046291.

Joh, C. H. et al. (2002) "Activity pattern similarity: A multidimensional sequence alignment method," Transportation Research Part B: Methodological. doi: 10.1016/S0191-2615(01)00009-1.

Kolb, D. a. (1984) "Experiential learning: Experience as the source of learning and development. Journal of Organizational Behavior. https://doi.org/10.1002/job.4030080408

Lenaghan, J. a. and Sengupta, K. (2007) "Role conflict, role balance and affect: A model of wellbeing of the working student," J Behav Appl Manag.

Malone, T. W., Laubacher, R. and Dellarocas, C. (2010) "The collective intelligence genome," IEEE Engineering Management Review, p. 38. doi: 10.1109/EMR.2010.5559142.

Mathis, R. L. and Jackson, J. H. (2002) Human Resource Management, Workforce. doi: 10.1055/s0030-1270560.

Mayer, J. D. et al. (2001) "Emotional Intelligence as a Standard Intelligence," Emotion. doi: 10.1037/1528-3542.1.3.232.

Mayer, J. D., Caruso, D. R. and Salovey, P. (1999) "Emotional Intelligence Meets Traditional Standards for an Intelligence," Intelligence, 27(4), pp. 267-298. doi: 10.1016/S01602896(99)00016-1.

McClelland, D. C. et al. (1998) "Identifying competencies with behavioral-event interviews," Psychological Science. doi: 10.1111/1467-9280.00065.

McCrae, R. R. and Costa, P. T. (1987) "Validation of the Five-Factor Model of Personality Across 
Instruments and Observers," Journal of Personality and Social Psychology. doi: 10.1037/00223514.52.1.81.

Peter Salovey, and J. D. M. (1990) “Emotional Intelligence," Imagination, cognition and personality, 9, pp. 185-211. doi: 10.1016/S0962-1849(05)80058-7.

Petrides, K. V. (2011) "Ability and Trait Emotional Intelligence," in The Wiley-Blackwell Handbook of Individual Differences, pp. 656-678. doi: 10.1002/9781444343120.ch25.

Rouach, D. and Santi, P. (2001) "Competitive Intelligence Adds Value: Five Intelligence Attitudes," European Management Journal, 19(5), pp. 552-559. doi: 10.1016/S0263-2373(01)00069-X.

Russell, S. J. (1997) "Rationality and intelligence," Artificial Intelligence, 94(1-2), pp. 57-77. doi: 10.1016/S0004-3702(97)00026-X.

Salovey, P. and Mayer, J. D. (1990) "Emotional Intelligence," Imagination, Cognition and Personality, 9, pp. 185-211. doi: 10.2190/dugg-p24e-52wk-6cdg.

Snape, E., Redman, T. and Wilkinson, A. (1993) "Human Resource Management In Building Societies: Making the Transformation?," Human Resource Management Journal. doi: 10.1111/j.1748-8583.1993.tb00315.x.

Sternberg, R. J. (1999) "Intelligence as Developing Expertise," Contemporary Educational Psychology, 24, pp. 359-375. doi: 10.1006/ceps.1998.0998.

Thoits, P. (2013) "The Relevance of Self and Identity Issues to Stress and Mental Health," in Handbooks of Sociology and Social Research. doi: 10.1007/978-94-007-4276-5_18.

Torrington, D., Hall, L. and Taylor, S. (2009) "Human Resource Management," Human Resource Management.

Trihandini, R. A. F. M. (2013) “Analisis Pengaruh Intellectual Intelektual , Intellectual Emosi dan Intellectual Spiritual terhadap Performance Karyawan Program Studi Magister Manajemen Program Pascasarjana Universitas Diponegoro Semarang," Unpiblished Phd Theses.

Ulrich, D. (1997) "Human Resource Champion The next agenda for adding value and delivering results," Academy of Management Review.

Vathanophas, Vichita; Thai-ngam, J. (2007) "Competency Requirements for Effective Job Performance in The Thai Public Sector," Contemporary Management Research. doi: http://dx.doi.org/10.7903/cmr.49.

Wechsler, D. (1958) "The measurement and appraisal of adult intelligence (4th ed.). Baltimore, MD, US: Williams \& Wilkins Co. http://dx.doi.org/10.1037/11167-000 